\title{
Streptomyces: isolation, optimization of culture conditions and extraction of secondary metabolites
}

\author{
*Ahmed I. Khattab ${ }^{1}$, Eltahir H. Babiker ${ }^{2}$ and Humodi A. Saeed ${ }^{3}$ \\ ${ }^{1}$ Microbiology Department, Al-Yarmouk College, Khartoum, Sudan \\ 2Department of Biochemistry, Faculty of Medicine and Health Science, University of El Imam El Mahadi, Sudan \\ ${ }^{3}$ College of Medical Laboratory Science, Sudan University of Science and Technology, Khartoum, Sudan
}

\begin{abstract}
The objectives of this study were to isolate and identify Streptomyces from soil sediments as well as to optimize cultural growth conditions for maximum antibacterial productivity. A total of fifty soil sediments were collected from Red Sea, Sudan. The soil sediments were pretreated and cultivated on agar medium. Promising Streptomyces spp. were isolated by agar overlay method using indicator organisms. Optimization of chemical and physical culture conditions was carried out. The later was judged by assessment of antibacterial activity. Ethyl acetate was used to extract the secondary metabolite compounds. The separation of the active ingredients was performed using both thin layer chromatography (TLC) and gas chromatography-mass spectrometer (GC-MS). The results revealed nine strains of Streptomyces. Of them two (PS1 and PS28) isolates exhibited high activity against pathogenic bacteria. The optimum growth conditions were $\mathrm{pH} 7.5$, temperature at $30^{\circ} \mathrm{C}$, soyabean concentration $2.5 \mathrm{~g} / \mathrm{l}$, incubation period in 7 days, $\mathrm{MgSO}_{4} .7 \mathrm{H}_{2} \mathrm{O}$ conc. $1 \mathrm{~g} / 1$ and $\mathrm{K}_{2} \mathrm{HPO}_{4}$ conc. $2.5 \mathrm{~g} / \mathrm{l}$. TLC test showed three and two fragments from metabolites of PS1 and PS28 respectively, while the GC-MS analysis revealed eight and eleven compounds with antibacterial activity of PS1 and PS28 respectively. It is concluded that marine is promising source of secondary metabolites.
\end{abstract}

Key Words: Streptomyces, Red Sea, antibacterial activity, GC-MS, Sudan.

\section{INTRODUCTION}

The increase of bacterial resistance to antibiotics is due to the concurrent usage of existing antibiotics, the search for new potent antibiotic to control these resistant pathogens, new antibiotics are in need and should be developed (Naine et al., 2015). The discovery of antibacterial metabolites from marine sources with a potent activity has been proved. Streptomyces spp. have the ability to produce many different biologically active secondary metabolites such as antibacterial (Nandhini and Selvam, 2013). Marine Streptomyces have a unique secondary metabolites variety by producing new natural antimicrobials. About $2 / 3$ of the famous antibiotics was produced by the genus Streptomyces. And about $75 \%$ of useful antibiotics are produced by the Streptomyces spices (Bhavana et al., 2014). There are about 23,000 recognized secondary metabolites and around $80 \%$ of which are produced by Streptomyces species. Many pathways are related with secondary metabolites produced by the genus Streptomyces, these include antimicrobial, antitumor and enzyme inhibitors, compared to terrestrial species, marine Streptomyces are essential sources of unique antibiotics. Therefore, the marine Streptomyces are investigated to extract secondary metabolites and there are many secondary metabolites have been screened recently (Vijayakumar et al., 2012). It is commonly acknowledged that new antibiotics are urgently required, and that the most promising sources are natural habitats. The marine environment is largely unexploited source for new antibiotics, in a view of the enormous diversity of microorganisms-producing secondary metabolites (Bull

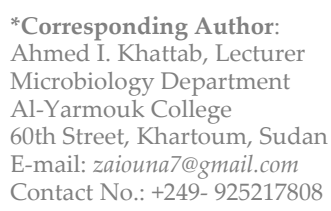

and Stach, 2007). The production of secondary metabolites from the genus Streptomyces can be influenced by optimization of the nutritional requirements and cultural conditions. These conditions play an important role in the production of these secondary metabolites (Al-Hulu, 2013).

\section{MATERIALS AND METHODS}

Isolation of Streptomyces

Fifty marine soil samples were collected from Port Sudan (Falamango coast area) in the depth vary from 0.5 to 20 meter (Average depth 10.5 meters). The samples were air dried to reduce bacterial and fungal contaminats, and stored at $4^{\circ} \mathrm{C}$ (Kathiresan et al., 2005).

One gram of soil was suspended in $4 \mathrm{ml}$ of sterile seawater. The suspension was heated for $6 \mathrm{~min}$ at $55^{\circ} \mathrm{C}$ to reduce non-spore forming bacteria. The contents were diluted (1:4) in sterile seawater. Aliquots of $1 \mathrm{ml}$ of the sample was spread onto the isolation media (Starch casein Agar (SCA) and International Streptomyces Project (ISP) No.7 media) were prepared and sterilized at $121^{\circ} \mathrm{C}$ in 15 lbs pressure for $15 \mathrm{~min}$ ) (Jensen et al., 2005). Rifampicin $5 \mu \mathrm{g} / \mathrm{ml}$ and Nystatin $25 \mu \mathrm{g} / \mathrm{ml}$ were added to prevent bacterial and fungal growth respectively. Plates were incubated at $30^{\circ} \mathrm{C}$ for 7 days (Panchagnula and Terli, 2011). Antibacterial activities of the obtained colonies were detected using agar overlay technique (Srinu, 2013).

\section{Identification of Streptomyces strain}

The DNA was extracted using Jena Bioscience bacterial DNA isolation and purification kit (Jena Bioscience Laboratories, $\mathrm{GmbH}$, Germany) according to the manufacturer instructions, and the 16S rDNA was amplified by PCR using a Maxime PCR PreMix kit (iNtRON, Korea). The primers and the PCR conditions were done according to Malinova (2014). 


\section{Primary Screening of Antibacterial Activity}

Antimicrobial activity was determined using agar well diffusion method (Augustine et al., 2005), with the test pathogenic bacteria Staphylococcus aureus ATCC 25923 and Escherichia coli ATCC 25922. The inhibition zones were recorded and only isolated strains with the broad spectrum activity were selected for more investigations.

\section{Optimization of growth and antimicrobial compounds production}

To test the growth and antimicrobial compounds production, (PS1 And PS28) isolates were inoculated into a $250 \mathrm{ml}$ Erlenmeyer flask containing $100 \mathrm{ml}$ Soyabean Casein Digest Medium (Tryptone Soya Broth), and the filtrate was detect tested for antibacterial activity by agar well diffusion method (Jeffrey and Halizah, 2014; Bhavana et al., 2014).

\section{Effect of nitrogen source}

Different soybean meal concentration (1.5, 2.5, 3.5 and 5 $\mathrm{g} / \mathrm{L}$ ) were added to the culture medium and incubate for 7 days at $30^{\circ} \mathrm{C}$.

\section{Effect of $\mathbf{p H}$}

To determine the optimal $\mathrm{pH}$ for antimicrobial compounds production, flasks containing $50 \mathrm{ml}$ of broth Soyabean Casein Digest Medium (Tryptone Soya Broth) adjusted to $\mathrm{pH}$ values of $(6.5,7,7.5$ and 8$)$. The broth medium was inoculated with Streptomyces isolates and the flasks were incubated at $30^{\circ} \mathrm{C}$ for 7 days on the shaker, and then the supernatants were tested for antimicrobial activity.

\section{Effect of Temperature}

Streptomyces isolates were inoculated in optimized medium and incubation at different temperatures ranging from $20,25,30$ and $40^{\circ} \mathrm{C}$ for 7 days.

\section{Optimum incubation period}

To study the influence of incubation period, the culture was inoculated in growth medium for 10 days. The broth was sequentially tested for antimicrobial disc sensitivity test in 4, 5, 6, 7, 8, 9 and 10 days. Inhibition zones were measured and the optimum period was fixed for other experiments.

\section{Effect of Dark and Light Conditions}

Two flasks containing culture media were incubated for 7 days in dark and light conditions.

\section{Effect of $\mathrm{MgSO}_{4} .7 \mathrm{H}_{2} \mathrm{O}$ concentration}

Different concentration of $\mathrm{MgSO}_{4} .7 \mathrm{H}_{2} \mathrm{O}(0.5,1,1.5$ and 2 $\mathrm{g} / \mathrm{L}$ ) were tested for optimum concentration in culture media.

\section{Effect of $\mathrm{K}_{2} \mathrm{HPO}_{4}$ concentration}

Different concentration of $\mathrm{K}_{2} \mathrm{HPO}_{4}(1,1.5,2.5$ and $4 \mathrm{~g} / \mathrm{L})$ were tested for optimum concentration in culture media.

\section{Fermentation}

The two selected strains Streptomyces (SP 1 and SP 28) isolates were inoculated into Trypton soya broth, and incubated at $30^{\circ} \mathrm{C}$ in a shaker for seven days.

After fermentation filtrate was separated by centrifugation at $5000 \mathrm{rpm}$ for $10 \mathrm{~min}$. and the supernatant was filtrated through Millipore filter (Millipore Millex-HV Hydrophilic PVDF $0.45 \mu \mathrm{m}$ ) (Remya and Vijayakumar,
2008). The filtrate was transferred aseptically into a conical flask and stored at $4^{\circ} \mathrm{C}$ for further assay.

\section{Extraction}

The culture filtrate $(200 \mathrm{ml})$ was extracted 3 times with solvent ethyl acetate. The solvent was added to the filtrate in the ratio of $1: 1(\mathrm{v} / \mathrm{v})$ and shaken vigorously for 20 minutes. The ethyl acetate phase that contains antibiotic was separated from the aqueous phase using separating funnel. Ethyl acetate layer was concentrated by evaporating to dryness at $40^{\circ} \mathrm{C}$ and residue obtained was purified using methanol to give $(0.8 \mathrm{~g})$ of brown crude extract (Ahmed 2007). This obtained compound was used to determine antibacterial activity against test pathogenic bacteria by agar-well diffusion method (Rabah et al., 2007).

\section{Secondary Screening of Antibacterial Activity}

The crude extract was tested for antimicrobial activity using agar-well diffusion method by spreading $25 \mu \mathrm{l}$ of $S$. aureus and E. coli on Muller-Hinton agar, the wells were dug by the help of sterile $6 \mathrm{~mm}$ cork-borer and loaded with the $100 \mu \mathrm{l}$ of crude metabolite.

The plates were left at $4^{\circ} \mathrm{C}$ for $12-16$ hours then incubated overnight at $37^{\circ} \mathrm{C}$. Inhibition zone of test microorganisms around the wells were measured (Augustine et al., 2005, Khan and Patel, 2011).

\section{Thin layer chromatography (TLC)}

To visualize the number of compounds present in the extract of isolates (PS1 and PS28), thin layer chromatography (TLC) was performed. Aluminum plates pre-coated with silica gel $\left(20 \times 20 \mathrm{~cm}, 0.25 \mathrm{~mm}\right.$ Alugram ${ }^{\circledR}$ SIL G/UV 254, Macherey and Nagel, Duren) and two mobile phases [ethyl acetate : methanol (6:4) and Petroleum ether : Chloroform (1:1)] (Attimarad et al., 2012).

Chromatograms were observed under UV light, fractions of the isolates retention factor $\mathrm{Rf}$ value were measured and the ratio calculated.

\section{Identification of bioactive compounds}

The antibacterial compounds were identified by using Gas Chromatography-Mass Spectrometer technique (GCMS) (Joel and Bhimba, 2012). The mass spectrum was recorded by using GC-MS-Shimadzu QP2010 Ultra, Japan.

\section{RESULTS}

Among fifty isolates obtained from marine soil sediment an agar overlay technique revealed that, $21(42 \%)$ showed antibacterial activities against both Gram-positive and Gram-negative bacteria. Polymerase chain reaction (PCR) was done to determine the identities of the 21 promising isolates revealed that nine $(n=9)(18 \%)$ were identified as Streptomyces species (PS1, PS5, PS10, PS13, PS20, PS21, PS23, PS24, and PS28). The antibacterial activity of the nine Streptomyces revealed that the strains PS1 and PS28 have the highly activity against pathogenic test bacteria. Maximum antibacterial production was observed among several concentration of soyabean meal (figure 1). The antibacterial activity was increasing continuously from $0.5 \mathrm{~g} / \mathrm{L}$ to $2.5 \mathrm{~g} / \mathrm{L}$ of soyabean meal concentration. Further increase in the soyabean meal concentration showed a gradual decrease in the production of antimicrobial compounds. The strains of Streptomyces showed high activity at $\mathrm{pH}$ with value between 7-7.5 (figure 2), the optimum activity of strains showed highly activity at $30^{\circ} \mathrm{C}$, while the activity was decreased at lower temperature (figure 3 ), the activity of strains against pathogenic 
microorganisms was at high peak in the range of 5-7 days of incubation, while it is decreased with other periods (figure 4.), the activity of antibacterial compounds exhibited there is no important difference between dark and light environment (figure 5), optimum concentration of $\mathrm{MgSO}_{4} .7 \mathrm{H}_{2} \mathrm{O}$ required for the production of antimicrobial compounds was $1 \mathrm{~g} / \mathrm{L}$. Further increase in $\mathrm{MgSO}_{4} .7 \mathrm{H}_{2} \mathrm{O}$ concentration showed a gradual decrease in the production of antimicrobial compounds (figure 6); optimum $\mathrm{K}_{2} \mathrm{HPO}_{4}$ concentration required for the production of antimicrobial compounds was $2.0 \mathrm{~g} / \mathrm{L}$. Further increase in the $\mathrm{K}_{2} \mathrm{HPO}_{4}$ concentration showed a gradual decrease in the production of antimicrobial compounds (figure 7). The two strains (PS1 and PS 28) were selected for the extraction of crude compound by ethyl acetate extraction method. Gummy brown crude extract was obtained. The antibacterial activity against $S$. aureus and $E$. coli by agar well diffusion method of crude extracted is shown in table 1.

The crude extracts by ethyl acetate were separated by TLC plates for the strain PS1 yielded three fractions (A, $B$ and C), while the strain PS28 yielded two fractions (A and B) (figure 8.). The Rf value for the strain $P S 1=0.7 \mathrm{~cm}$, while the value for $P S 28=0.6 \mathrm{~cm}$.

The GC-MS analysis showed the chemical composition of extract of isolate PS1 were 54 compounds, while the isolate PS28 were 96 compounds. From these compounds the isolate PS1 eight bioactive compounds is identify with antimicrobial activity (table 1), while the isolate PS28 eleven compounds identify with antimicrobial activity (table 2).

\section{DISCUSSION}

The resistance of numerous pathogenic bacteria to antibiotics necessitate search for new antibacterial agents to fight these pathogens. Secondary metabolites produced by bacteria still interested, due to their complicated chemical structures and highly specific antimicrobial activities. The soil bacteria resembling to the genus Streptomyces are rich sources of large number of bioactive natural products; they are widely used as antimicrobials. Streptomyces species produce about $75 \%$ of useful antibiotics (Kumar et al., 2014). Al-Zahrani, (2007) reported that incubation conditions influence the qualitative production of secondary metabolites by Streptomyces species. Kathiresan et al., (2005) reported that ability of bacteria to produce antimicrobial agents can be increased or lost under different culture conditions. Maximum antibiotic production was observed with soyabean meal as a source of nitrogen compared to other compounds. The present study confirmed this fact as soyabean meal was used in this study to influence the production of antibacterial compounds; the $\mathrm{pH}$ values affect the cellular metabolisms and biosynthesis of secondary metabolites in Streptomyces species (Bhavana et al., 2014). In this study, the $\mathrm{pH}$ was found suitable for maximum production of metabolites near the neutral value. Ripa et al., (2009) reported that extreme $\mathrm{pH}$ is unfavorable for production of secondary metabolites. Kokare et al., (2007) showed that $28^{\circ} \mathrm{C}$ is the optimum temperature, while $30^{\circ} \mathrm{C}$ was the optimum temperature for maximum production of metabolites in this study. Our study showed that incubation period was 7 days. Kathiresan et al., (2005) reported that 5 days of incubation gave the broad activity of secondary metabolites. Ethyl acetate was used extensively to extract secondary metabolites. Ghadin et al., (2008) reported that the extraction of secondary metabolites by ethyl acetate

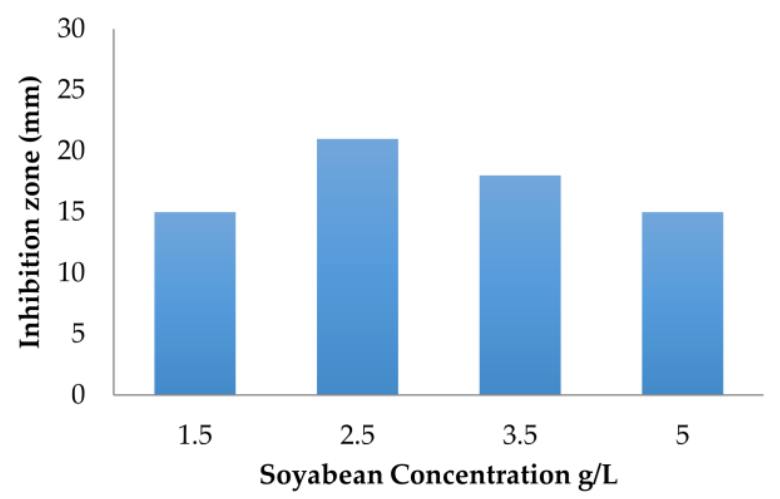

Figure 1: Effect of nitrogen source.

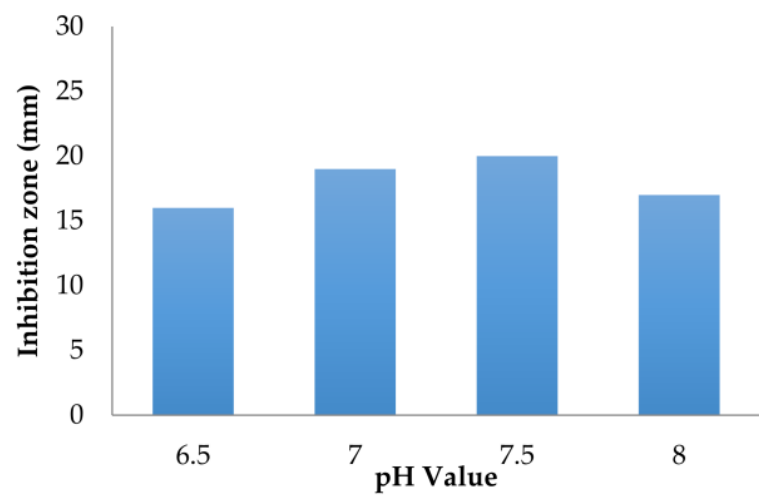

Figure 2: Effect of $\mathrm{pH}$ value.

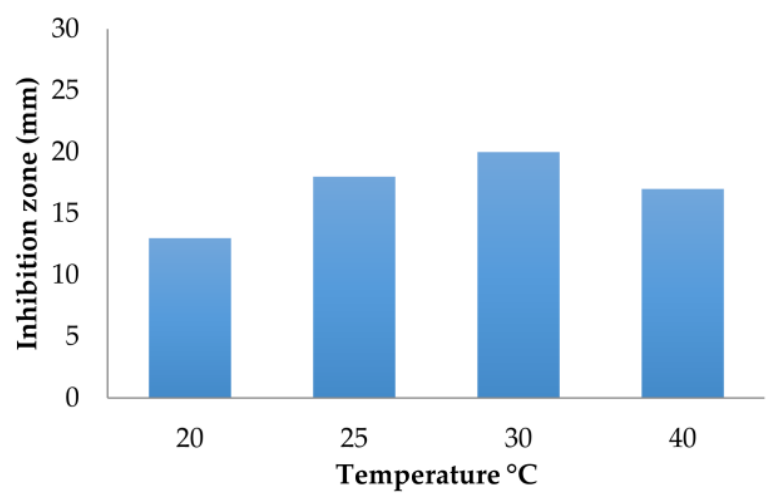

Figure 3: Effect of temperature.

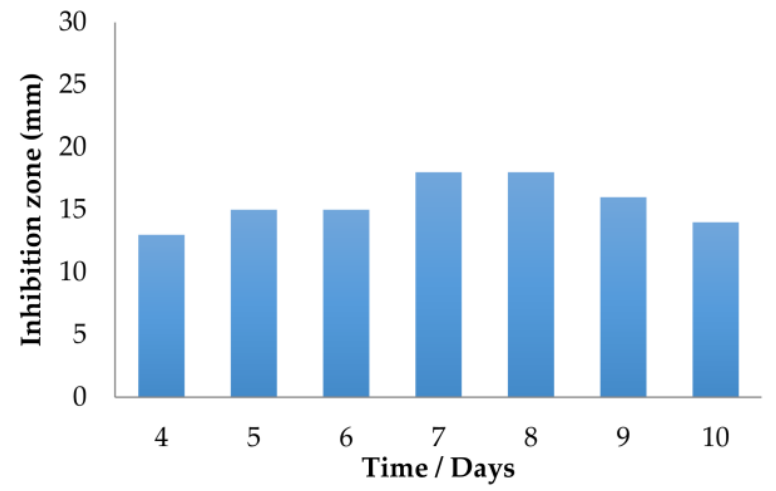

Figure 4: Effect of incubation perioid. 


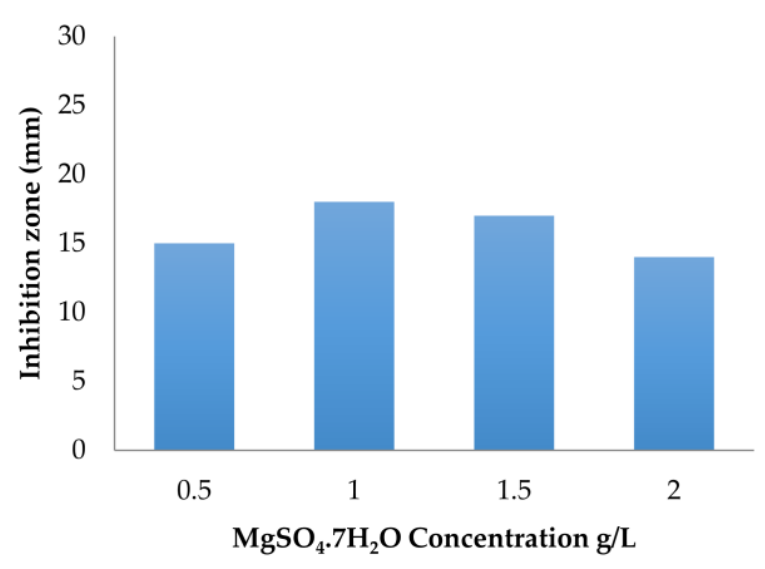

Figure 5: Effect of $\mathrm{MgSO}_{4} .7 \mathrm{H}_{2} \mathrm{O}$ concentration.

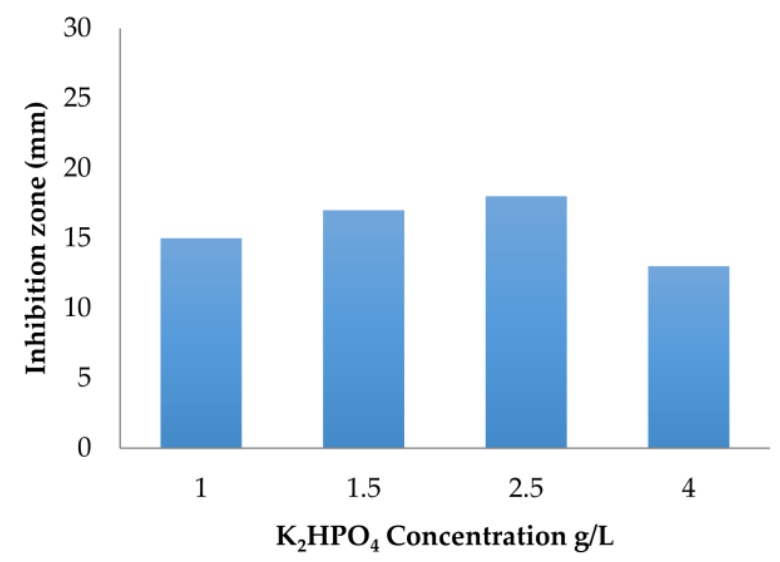

Figure 6: Effect of $\mathrm{K}_{2} \mathrm{HPO}_{4}$ concentration.

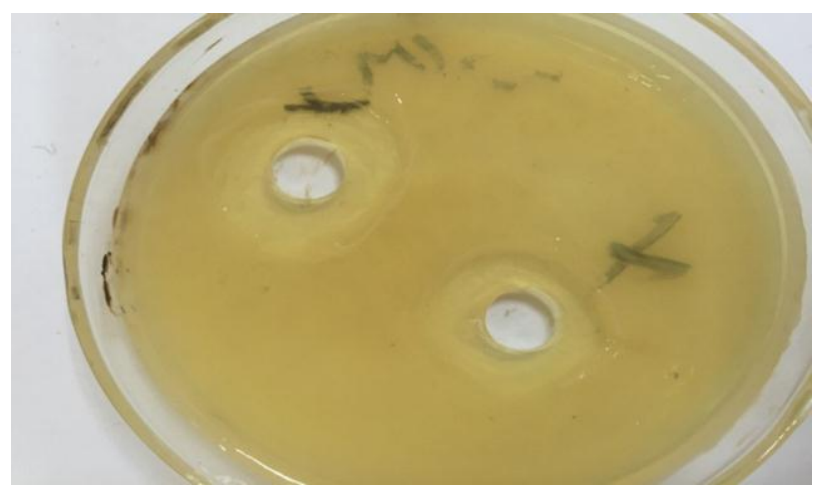

Figure 7: The inhibition zone (mm) of PS1 and PS28 against $S$. aureus.

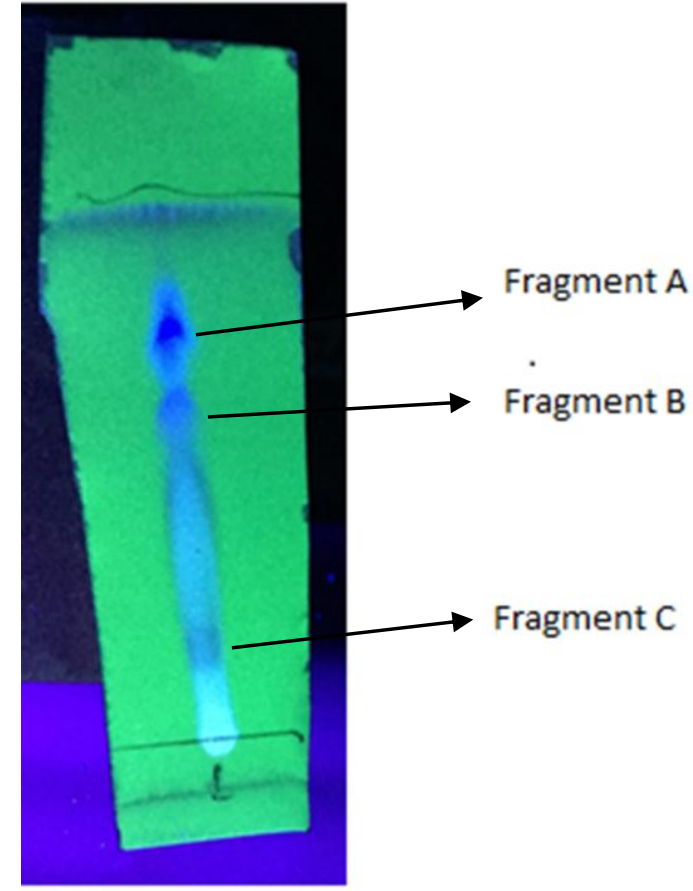

Figure 8: TLC plate of PS1 showing fragments.

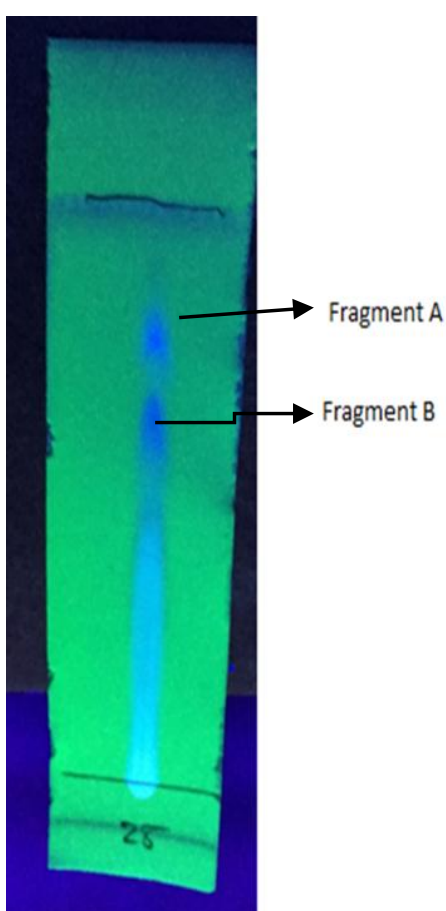

Figure 9: TLC plate of PS28 showing fragments. 
Table1: Compounds identify with antimicrobial activities of PS1 isolate.

\begin{tabular}{|c|c|c|c|c|c|c|}
\hline $\begin{array}{c}\text { Compound } \\
\text { No. }\end{array}$ & Compound name & R-Time & $\begin{array}{c}\text { Similarity } \\
\%\end{array}$ & Area \% & $\begin{array}{l}\text { Compound } \\
\text { formula }\end{array}$ & $\begin{array}{c}\text { Molecular } \\
\text { weight }\end{array}$ \\
\hline I & 4-Vinyl-imidazole & 6.727 & 96 & 2.52 & $\mathrm{C}_{5} \mathrm{H}_{6} \mathrm{~N}_{2}$ & 94 \\
\hline II & Ornithine & 8.595 & 95 & 5.2 & $\mathrm{C}_{5} \mathrm{H}_{12} \mathrm{~N}_{2} \mathrm{O}_{2}$ & 132 \\
\hline III & 4-Methyleneproline & 13.055 & 96 & 15.02 & $\mathrm{C}_{6} \mathrm{H}_{9} \mathrm{NO}_{2}$ & 127 \\
\hline IV & Pyrimidinone, 6-amino-2-methyl & 15.712 & 95 & 0.82 & $\mathrm{C}_{5} \mathrm{H}_{6} \mathrm{~N}_{4} \mathrm{O}_{2}$ & 154 \\
\hline $\mathrm{V}$ & 2,6-Dibuty1-4-methylpiperidine & 15.879 & 95 & 2.70 & $\mathrm{C}_{14} \mathrm{H}_{29} \mathrm{~N}$ & 211 \\
\hline VI & Actinomycin C2 & 15.809 & 99 & 0.46 & $\mathrm{C}_{63} \mathrm{H}_{88} \mathrm{~N}_{12} \mathrm{O}_{16}$ & 1268 \\
\hline VII & n-3-imidazol-1-yl-propyl-n-4-isopropyl-phenyl-oxalamide & 20.024 & 98 & 2.14 & $\mathrm{C}_{17} \mathrm{H}_{22} \mathrm{~N}_{4} \mathrm{O}_{2}$ & 314 \\
\hline VIII & 5-nitroso-2,4,6-triaminopyrimidine & 22.817 & 98 & 5.79 & $\mathrm{C}_{4} \mathrm{H}_{6} \mathrm{~N}_{6} \mathrm{O}$ & 154 \\
\hline
\end{tabular}

Table 2: Compounds identify with antimicrobial activities of PS28 isolate.

\begin{tabular}{|c|c|c|c|c|c|c|}
\hline $\begin{array}{c}\text { Compound } \\
\text { No. }\end{array}$ & Compound name & R-Time & $\begin{array}{c}\text { Similarity } \\
\%\end{array}$ & $\begin{array}{c}\text { Area } \\
\%\end{array}$ & $\begin{array}{l}\text { Compound } \\
\text { formula }\end{array}$ & $\begin{array}{c}\text { Molecular } \\
\text { weight }\end{array}$ \\
\hline IX & pyrrolidine n 3-methyl-3- butenyl & 3.870 & 97 & 0.67 & $\mathrm{C}_{9} \mathrm{H}_{17} \mathrm{~N}$ & 139 \\
\hline $\mathrm{x}$ & Piperidine, 2,3-dimethyl & 4.875 & 96 & 0.14 & $\mathrm{C}_{7} \mathrm{H}_{15} \mathrm{~N}$ & 113 \\
\hline $\mathrm{XI}$ & Cyclohexanamine, $\mathrm{N}$-2-propenyl & 7.793 & 96 & 0.17 & $\mathrm{C}_{9} \mathrm{H}_{17} \mathrm{~N}$ & 139 \\
\hline XII & alpha-campholenal & 8.329 & 96 & 1.0 & $\mathrm{C}_{10} \mathrm{H}_{16} \mathrm{O}$ & 152 \\
\hline XIII & Norvaline & 15.072 & 99 & 6.07 & $\mathrm{C}_{26} \mathrm{H}_{47} \mathrm{NO}_{4}$ & 437 \\
\hline XIV & 2-Piperidinone & 15.415 & 98 & 0.51 & $\mathrm{C}_{10} \mathrm{H}_{16} \mathrm{~N}_{2} \mathrm{O}$ & 180 \\
\hline $\mathrm{XV}$ & 1-leucine, n-cyclopropylocarbonyl- pentadecyl ester & 15.783 & 99 & 5.76 & $\mathrm{C}_{25} \mathrm{H}_{47} \mathrm{NO}_{3}$ & 409 \\
\hline XVI & 5,10-diethoxy-2,3,7,8-tetrahydro-1h,6h-dipyrrolo[1,2-a;1,2-d]pyrazine & 16.059 & 97 & 6.21 & $\mathrm{C}_{14} \mathrm{H}_{22} \mathrm{~N}_{2} \mathrm{O}_{2}$ & 250 \\
\hline XVII & n(1) 3-methyl-1,2,4-oxadiazole & 17.737 & 95 & 0.55 & $\mathrm{C}_{9} \mathrm{H}_{15} \mathrm{~N}_{5} \mathrm{O}$ & 209 \\
\hline VII & n-3-imidazol-1-yl-propyl-n-4-isopropyl-phenyl-oxalamide & 20.062 & 99 & 5.65 & $\mathrm{C}_{17} \mathrm{H}_{22} \mathrm{~N}_{4} \mathrm{O}_{2}$ & 314 \\
\hline VIII & 5-nitroso-2,4,6-triaminopyrimidine & 22.914 & 98 & 7.23 & $\mathrm{C}_{4} \mathrm{H}_{6} \mathrm{~N}_{6} \mathrm{O}$ & 154 \\
\hline
\end{tabular}

showed the obvious activity against pathogenic bacteria than other solvent. Similar result was obtained in this study when used in ratio $1: 1$. In recent years GC-MS studies have been increasingly applied for the analysis medical used components (Nandagopalan et al., 2015).

In this study the GC-MS analysis showed a variety of compounds from the extract of PS1 and PS28, Jalaluldeen et al., (2015) revealed that 77 compounds were gain from GC-MS analysis, this is higher than PS1 strain compounds and lower than PS28 strain compounds. Many of these compounds are responsible for the antibacterial activity that detected in this study.

\section{CONCLUSION}

The study concluded that marine is promising habitat Streptomyces spp. and optimizing of culture conditions may influence the production of secondary metabolites. The GC-MS as a new technology is useful for separation components that exist in secondary metabolites.

\section{ACKNOWLEDGEMENT}

The authors would like to thank the Research Laboratory, College of Medical Laboratory Science, Sudan University of Science and Technology for their assistance where this study was conducted, also very grateful for the National Laboratory, Khartoum, Sudan for providing the Microorganisms used in this study.

\section{REFERENCES}

Ahmed, A. A. (2007). Production of antimicrobial agent by Streptomyces Viola chromogen. Saud J. of Biological Sciences, 14, 7-16.

Al-Hulu, S. M. (2013). Study effects of some parameters on antifungal activity for Streptomyces spp. Journal of Kerbala University, 11 (3).

Al-Zahrani, S. H. M. (2007). Studies of antimicrobial activity of Streptomyces sp. Isolated from Jazan. JKAU, 19(1), 127-138. [DOI]

Attimarad, S. L., Ediga, L. G., Karigar, A. A., Karadi, R., Chandrashekhar, N. and Shivanna, C. (2012). Screening, isolation and purification of antibacterial agents from marine actinomycetes. International Current Pharmaceutical Journal, 1(12), 394-402. [DOI]
Augustine, S. K., Bhavsar, S. P. and Kapadnis, B. P. (2005). A non-polyene antifungal antibiotic from Streptomyces albidoflavus PU 23. Journal of Biosciences, 30(2), 201-211. [DOI]

Bhavana, M., Talluri, V. P., Kumar, K. S. and Rajagopal, S.V. (2014). Optimization of culture conditions of Streptomyces carpaticus (mtcc11062 ) for the production of antimicrobial compound. International Journal of Pharmacy and Pharmaceutical Sciences, 6 (8), 281-285.

Bull, A.T. and Stach, J.E.M. (2007). Marine actinobacteria: new opportunities for natural product search and discovery. Trends in microbiology, 15(11), 419-499. [DOI]

Ghadin, N., Zin, N. M., Sabaratnam, V., Badya, N., Basri, D. F., Lian, H. H. and Sidik, N. M. (2008). Isolation and characterization of a novel endophytic Streptomyces SUK 06 with antimicrobial activity from Malaysian plant. Asian J. Plant Sci., 7(2), 189-197. [DOI]

Jalaluldeen, A. M., Sijam, K., Othman, R. and Ahmad, Z. A. M. (2015). Growth characteristics and production of secondary metabolites from selected Streptomyces species isolated from the Rhizosphere of Chili Plant. International Journal of Enhanced Research in Science Technology and Engineering, 4 (1), 1-8.

Jeffrey, L. S. H. and Halizah, H. (2014). Impact of media composition and growth condition of antifungal production by Streptomyces ambofaciens S2. African journal of microbiology research, 8(10), 994-1000. [DOI]

Jensen, P. R., Gontang, E., Mafnas, C., Mincer, T. J. and Fenical, W. (2005) Cultural marine actinomycete diversity from tropical Pacific Ocean sediments. Applied and Environmental Microbiology, 7 (7), 1039-1048. [DOI]

Joel, E. L. and Bhimba, B. V. (2012). Fungi from mangrove plants: their antimicrobial and anticancer potentials. Int. J Pharm Pharm. Sci., 4 (3), 139-142.

Kathiresan, K., Balagurunathan, K. and Selvam, M. M. (2005). Fungicidal activity of marine actinomycetes against phytopathogenic fungi. Indian journal of Biotechnology, 4, 271- 276.

Khan, J. A. and Patel, A. S. (2011). Extraction and purification of antibacterial metabolites from actinomycetes spp. Isolated from soil samples. International journal of pharmaceutical research and development, 3 (10), 63-71.

Kokare, C.R., Kadam, S. S., Mahadik, K. R. and Chopade, B. A. (2007). Studies on bio emulsifier production from marine Streptomyces sp. Indian J. of Biotechnology, 16, 78-84.

Kumar, P. S., Al-Dhabi, N. A., Duraipandiyan, V., Balachandran, C., Kumar, P. P. and Lgnacimuthu, S. (2014). In vitro antimicrobial, antioxidant and cytotoxic properties of Streptomyces lavendulae strain SCA5. BMC Microbiology, 14(1), 291. [DOI] 
Malinovaa, M. E., Stoyanovab, M., Avramovaa, H., Pavlovaa, Y., Gochevaa, B., Ivanovaa, I. and Monchevaa, P. (2014). Antibacterial potential of streptomycete strains from Antarctic soils. Biotechnology and Biotechnological Equipment, 28(4), 721-727. [DOI]

Naine, S. J., Devi, C. S., Mohanasrinivasan, N. and Vaishnavi, B. (2015). Antimicrobial, Antioxidant and Cytotoxic Activity of Marine Streptomyces parvulus VITJS11 Crude Extract. Braz. Arch. Biol. Technol, 58 (2), 198-207. [DOI]

Nandagopalan, V., Gritto, M.J. and Doss, A. (2015). GC-MS analysis of bioactive components of the methanol extract of Hibiscus tiliaceus Linn Asian Journal of Plant Science and Research, 5(3), 6-10.

Nandhini, S. U. and Selvam, M. M. (2013). Bioactive compounds produced by Streptomyces strain. International Journal of Pharmacy and Pharmaceutical Sciences, 5 (1), 176-178.

Panchagnula, B. and Terli, R. (2011). Screening of marine sediments from Bay of Bengal near Pudimadaka Coast of Andhra Pradesh for isolation of lipolytic actinobacteria and characterization of the most potent isolates. International Journal of Biology, 3 (1). [DOI]
Rabah, V. L., Saker. E. M., Cheikh, B. and Kocine, M. (2007). Screening, isolation and characterization of a novel antimicronbial producing actinomycete, strain RAF10. Biotechnology, 6(4), 489-496. [DOI]

Remya, M., and Vijayakumar, R. (2008). Isolation characterization of marine antagonistic actinomycetes from west coast of India. Medicine and Biology, 15, 13-19.

Ripa, F. A., Nikkon, F., Zaman, S. and Khondkar, P. (2009). Optimal conditions for antimicrobial metabolites production from a new Streptomyces sp. RUPA-08PR isolated from Bangaladeshi soil. Mycobiolgy, 37(3), 211-214. [DOI]

Srinu, M., Kumar, M. M. and Shankar, G. G. (2013). Actinomycin “D” from marine sediment associated Streptomyces capillispiralis MTCC10471. AJPRHC, 5, (1), 16-23.

Vijayakumar, R., Panneerselvam, K., Muthukumar, C., Thajuddin, N., Panneerselvam, A. and Saravanamuthu, R. (2012). Optimization of Antimicrobial Production by a Marine Actinomycete Streptomyces afghaniensis VPTS3-1 Isolated from Palk Strait, East Coast of India. Indian J Microbiol, 52(2), 230-239. [DOI] 